\section{Accreditation standard suggestions for teaching Turkish to foreigners ${ }^{1}$}

\section{Yabanc1lara Türkçe öğretimi için akreditasyon standart önerileri}

\section{Alparslan İkiel ${ }^{2}$}

\section{Özet}

Son yillarda Türkiye Cumhuriyeti'nin bulunduğu coğrafyadaki çeşitli ülkelerin gerek kendi iç çatışmaları gerekse de diğer ülkelerin farklı müdahaleleri ile yaşanan çatışmalar nedeniyle Türkiye'ye göç hareketleri gerçekleşmiştir. Diğer yandan küreselleşen dünyada yaşanan uluslararası öğrenci hareketliliğinde bölgesel ve ulusal bir güç olma yönündeki durumu, Türkiye'yi tercih eden yükseköğretim ögrencilerinin sayısının giderek artmasına neden olmuştur. Bu nedenler Türkçenin yabancilara öğretiminin bazı akredite standartlarının olmasını gündeme getirmiştir. Türk dilini bilmeyen bu nüfusun yaşamlarını sürdürebilmeleri insani hizmetlerden yararlanabilmeleri için bulundukları sosyal ortam ve devlet kurumları ile iletişim halinde olmalarını gerektirmiştir.

Bu iletişimi sağlıklı bir şekilde gerçekleştirmeleri için dil öğrenimi ve kullanımı önemli bir ihtiyaç haline hale gelmiştir. Bu gelişmelere bağlı olarak yabancilara Türkçe öğretimine ciddi bir talep oluşmuştur. Yabancilara Türkçe öğretimi alanında eğitim veren dil okullarında bir kalite algisı oluşması önemlidir. $\mathrm{Bu}$ algının kurumsallaşabilmesi amacı ile ileride kurulabilecek Türkçe öğretiminde akreditasyon derneğine kalite standartları önerisi sunabilmek

\footnotetext{
1 This study were obtained from the postgraduate thesis under the supervision of Dr. Mehmet Barıs Horzum.

2 M.A., Sakarya University, Turkish language teaching practice and research center, (D) Orcid ID: 0000-0002-5725-6168
} 
İkiel, A. (2020). Yabancılara Türkçe öğretimi için akreditasyon standart önerileri. Journal of Human Sciences, 17(3), 780-791. doi:10.14687/jhs.v17i3.6022

Keywords: Accreditation in Language Teaching, önemli bir ihtiyaçtır. Bu araştırmanın amacı Teaching Turkish to Foreign Nationals, yabancılara Türkçe öğretimi yapan kurumlar için Accreditation Standard. akreditasyon standart önerileri geliştirmektir.

(Extended English summary is at the end of this document)

Anahtar Kelimeler: Dil Öğretiminde Akreditasyon, Yabancı Uyruklulara Türkçe Öğretimi, Akreditasyon Standartları.

\section{Giriş}

Son yüzyılda dünyada ticaretin, teknolojinin, yükseköğretimin, sosyal unsurların, kültürün vb. küreselleşmesi ile insanların yabancı dil öğrenimi artık bir ayrıcalık değil kaçınılmaz bir ihtiyaç haline gelmiştir. Türkiye'nin 21. yüzyılda bölgesel ve küresel anlamda yaptuğ1 ekonomik ve insani atılımlar yabancı uyruklu kişilere Türkçe öğretimine büyük bir hareket kazandırmış ve ihtiyaç için öğrenilen diller arasına Türk dilini de dâhil etmiştir. Bu yönüyle Türk dilinin bir dünya dili olması yolunda büyük bir adım atması sağlanmıştır. İçişleri Bakanlığı İl Göç İdaresi Başkanlığı'nın verilerine bakıldığında Türkiye'de ikamet izni ile bulunan yabancı uyrukluların sayısı 2009 yılından 2019'a 163.326'dan 975.472'ye ulaşmış, geçici koruma ile Türkiye'de barınan sadece Suriye Arap Cumhuriyeti vatandaşı sayısı ise 2019 yllı için 3.606.737'e ulaşmıştır (WEB1, 2019). Türkiye'deki yükseköğretim istatistikleri incelendiğinde Türkiye'de üniversite düzeyinde eğitim alan yabanc1 uyruklu öğrenci sayıs1 2018 yll için 125.138'dir (WEB2, 2019). Hayatına Türkiye'de devam eden ve sayısı milyonlarla ifade edilen yabanc1 uyruklu kişilerin sosyal hayatları düşünüldügü zaman bu kişilerin ülkemizde eğitim alanında, iş alanında ve komşuluk ilişkilerinde sağlıklı bir iletişim kurabilmeleri, topluma entegre olabilmeleri ve kültürümüzü anlayarak hayatlarını Türkiye'de devam ettirebilmeleri için Türk dilini akıcı olarak konuşabilmeleri, Türkçeyi ileri düzeyde öğrenmeleri büyük önem arz etmektedir.

İnternet ve sosyal medya gibi teknolojik gelişmelerle küreselleşen, insanlar arası ilişkilerin her alanda arttığı dünyada yabancı dil ya da diller öğrenme giderek önem kazanmıştır. Gökalp (1975), kültür için "Bir milletin dinî, ahlaki, akli, estetik, lisani, iktisadi ve fennî hayatlarının ahenkli bir bütünüdür” demiştir. Yabancı bir dil öğrenmeye başlamak, aynı zamanda o kültürü de anlamaya ve tanımaya başlamak demektir. Kültürün öğretilmediği bir dil eğitimi, dil eğitimi değil ancak o dilin kurallarının ezberletilmesi anlamına gelir (Okur ve Keskin, 2013).

Avrupa Birliği ülkeleri, diğer alanlarda gerçekleştirdikleri ortak çalışmaları dil eğitimi alanında da oluşturabilmek için 2001 yllında 'Avrupa Diller Yılı' etkinliklerinde dil öğretimi ders programlarını, ders araç gereçlerini ve öğretim yöntemlerini oluşturan “Ortak Dil Kriterleri Çerçeve Programını” kamuoyuna duyurmuştur (Güler, 2005). Türkiye Cumhuriyeti Millî Eğitim Bakanlığ1 Çerçeve Programı'nın Türkiye'de dil öğretiminde kullanılabilmesi için 2013 yılında Türkçe çevirisini yayınlamıştır. Ortak öneriler çerçevesi; dil öğretim yöneticilerine, ders kitabı yazarlarına, eğitimcilere öneriler sunmaktadır. Bu malzemelerle, dil öğretenlerin çalışmalarını yeniden değerlendirip bir standartlar sistemine oturtmalarını, birbirleriyle koordine çalışmalarını ve dil öğrenenlerin gerçek gereksinimlerini karşlayabilmeleri hedeflenmiştir (CEF, 2001).

Akreditasyon, toplam kalite hizmetlilerinin içinde yer alan faktörlerden biri olup dünya üzerinde birçok ülkede ve birçok alanda kamuoyuna sunulan program ve hizmetlerin kalitesinin sistematik bir yaklaşımla garanti altına alınması için oluşturulmuş bir yöntemdir (Gencel, 2001). Akreditasyon ile yükseköğretim kurumları kalite göstergelerine sahip olduklarını ileri sürüp bunu akreditasyon sertifikası alarak kanıtlar ve bu şekilde üniversite öğrenci adaylarının seçimlerini etkilemeye çalışırlar (Hesapçığlu, Bakioğlu, ve Baltacı, 2001). Aktan ve Gencel (2007) akreditasyonu kısa zamanda para karşıllğı diploma ya da sertifika sağlayan kalitesiz yükseköğretim kurumlarının toplum tarafindan fark edilmesine yardımcı olabilecek bir kalite sistemi olarak betimlemiştir. Bu kapsamda, akredite olan bir yükseköğretim kurumunun akademisyenleri, 
İkiel, A. (2020). Yabancilara Türkçe öğretimi için akreditasyon standart önerileri. Journal of Human Sciences, 17(3), 780-791. doi:10.14687/jhs.v17i3.6022

müfredat1, yönetimi ve öğrencilere sunulan hizmetleri açısından kurumun akreditasyon derneği tarafından belirlenen kalite standartları için yeterlilik sağladığının göstergesi olarak nitelendirilebilir (Ülker, 2015).

Türkiye'de öğrenim gören yabanc1 uyruklu yükseköğretim öğrencilerinin sayısı yıldan yıla büyük bir ivme ile artmıştır. Yükseköğretim Kurulu verilerine göre Türkiye'de üniversite öğrenimi gören yabancı uyruklu öğrenci sayısı tablo 1'de yer almaktadır;

Tablo 1. Türkiye’de Eğitim Alan Yabanc1 Uyruklu Öğrenciler (WEB2, 2019).

\begin{tabular}{lccccc}
\hline & $2013-2014$ & $2014-2015$ & $2015-2016$ & $2016-2017$ & $2017-2018$ \\
\hline Erkek Öğrenci & 33.431 & 49.635 & 60.156 & 71.854 & 81.783 \\
Kadın Öğrenci & 14.752 & 22.543 & 27.747 & 36.222 & 43.355 \\
Toplam Öğrenci & 48.183 & 72.178 & 87.903 & 108.076 & 125.138 \\
\hline
\end{tabular}

Tablo 1'de görülen yabancı uyruklu öğrenci sayısındaki artışı destekleyen ve Türk üniversitelerini diğer ülkelerde tanıtan yabancı öğrenci adaylarında farkındalık sağlayan faktörlerden birisi 2010 y1lında başbakanlık bünyesinde kurulan Yurtdış Türkler ve Akraba Topluluklar Başkanlığı'dır. YTB tarafindan 2014-2017 yılları arasında Türkiye'de burs imkânı sağlanan yükseköğrenim öğrencilerinin sayılanı şöyledir;

Tablo 2. YTB tarafindan burslandırılan öğrenci sayıları (WEB3, 2018).

\begin{tabular}{lcccc}
\hline & 2014 & 2015 & 2016 & 2017 \\
\hline Başvuru Sayısı & 81.745 & 155.000 & 155.000 & 106.550 \\
Burslandırılan Öğrenci Sayıs1 & 3.524 & 5.366 & $<4000$ & 5.378 \\
\hline
\end{tabular}

2016 y1lı itibarıyla Türkiye'de 85 farklı Türkçe Öğretim Merkezi faaliyetlerini sürdürmektedir (Boylu ve Başar, 2016). Fakat bu dil öğretim merkezlerinde herhangi bir standartlar bütünün olmaması toplam kalite hizmetleri dışında eğitim-öğretim programlarında, seviye tespit sınavları, kurların kaç hafta ve saatte tamamlanacağı gibi ders işleniş düzenlerinde kurumlar arası birçok farkliliklara neden olmuştur.

İnternet sayfaları üzerinden elde edilen verilere göre dönemlik eğitim sürelerini paylaşan TÖMER'ler arası kur saati ve süresi farklılıkları aşağıdaki gibidir;

Tablo 3. Türkçe öğretim merkezlerinin toplam ders saatleri

\begin{tabular}{lc}
\hline \multicolumn{1}{c}{ Kurum Adı } & A1-C1 Düzeyi Toplam Ders Saati \\
\hline ÇOMU TÖMER & 750 Ders Saati \\
GAZİ TÖMER & 850 Ders Saati \\
AKDENİZ TÖMER & 840 Ders Saati \\
AYDIN TÖMER & 760 Ders Saati \\
YILDIZ TÖMER & 960 Ders Saati \\
SELÇUK TÖMER & 1020 Ders Saati \\
ERCIYES ERSEM & 960 Ders Saati \\
\hline
\end{tabular}


Tablo 3 incelendiğinde kur saatleri arasında büyük farklılıklar göze çarpmaktadır. Çanakkale Onsekiz Mart Üniversitesi TÖMER'de A1 seviyesinde dil eğitimine başlayan ve Türkçe bilmeyen bir öğrencinin C1 seviyesini tamamlama süresi 750 ders saati olarak planlamışken aynı süreç Selçuk Üniversitesi TÖMER'de 1020 ders saati olarak planlamıştır.

Türkçe öğretim merkezlerinde yapılan seviye belirleme sınavlarında puan aralıkları arasında çok ciddi farklılıklar göze çarpmaktadır.

Tablo 4. Yabancı Dil Olarak Türkçe Öğretimi Sağlayan kurumların Türkçe Yeterlik Sınavları için Kullandıkları Ölçme ve Değerlendirme Puan Aralıkları (Boylu, 2019).

\begin{tabular}{lcc}
\hline Kurum Ad1 & Yeterlik Sinavi Puan Aralı̆̆1 & Dil Becerisi Denkliği \\
\hline & $85-100$ & C2 \\
MERSiN TUAM & $70-84$ & C1 \\
& $55-69$ & B2 \\
& $40-54$ & B1 \\
& $20-39$ & A2 \\
YUNUS EMRE & $0-19$ & A1 \\
ENSTITÜSÜ & $89-100$ & C2 \\
ÇUKUROVA & $71-88$ & C1 \\
TÖMER & $55-70$ & B2 \\
AYDIN TÖMER & $90-100$ & C2 \\
& $80-89$ & C1 \\
& $70-79$ & B2 \\
& $60-69$ & B1 \\
& $50-59$ & A2 \\
& $20-49$ & A1 \\
& $71-100$ & C1 \\
$60-70$ & B2 \\
& $60-65$ & B2 \\
\hline
\end{tabular}

Tablo 4'te verilen bilgilere göre kurumlar arasında verilen sertifikaların düzey geçerlilikleri üzerinde ciddi bir farklılık olduğu söylenebilir. Bu puan aralıklarının belirlenmesi daha önceden çalışmış ölçeklere göre düzenlenmediğini söylemek güç değildir. $\mathrm{Bu}$ durumun yol açtğ́ problemlerden birisi de bir kurumdan alınan Türkçe sertifikasının puanın düşük olması sonucu başka üniversitede eğitim alacak olan öğrencinin diğer üniversiteye göre dil yeterliliği düşük seviyede kalabilmesi veya yabancı uyruklu öğrencilerinin düşük puanla sertifika veren Türkçe öğretim merkezinden aldığı sertifika ile diğer üniversitelerde yükseköğretim eğitimine başlayabilmesidir.

Yabancılara Türkçe öğretimi gerçekleştirmek üzere hizmet veren dil öğretim merkezlerinin genel olarak aynı misyonu benimsedikleri görülse de dil öğretim süreçlerinde büyük farklıklarla birbirlerinden ayrıştıkları belirlenmiştir. Belirlenen farklılıkların asgari düzeye düşürülmesi dil 
İkiel, A. (2020). Yabancılara Türkçe öğretimi için akreditasyon standart önerileri. Journal of Human Sciences, 17(3), 780-791. doi:10.14687/jhs.v17i3.6022

öğretim merkezlerinin öğretim programı, kur sınavları, dil öğrenenlere verilen hizmetler vb. gibi kıstasların birbirine benzeştirilmesi sağlanarak okullar arasında koordinasyon ve uyum sağlanmalıdır. Dil ögretim merkezlerinin özgün yapılarını koruyarak ortak kalite standartlarına sahip olmaları, Türkçe öğretim merkezlerinde bir kalite algısı oluşması ve bu algının kurumsallaşabilmesi amacıyla ilerleyen yıllarda kurulabilecek Türkçe öğretiminde akreditasyon derneğine kalite standartları önerisi sunabilmek bu çalışmanın amacını oluşturmaktadır.

Türk kültürünün dünyaya açlan en önemli kapılarından biri olan Türkçe öğretim merkezlerinde sürdürülebilir bir kalite farkındalı̆̆ı oluşturulması için alanda akreditasyon derneğine ve temel standartlar tablosuna ihtiyaç duyulmaktadır. Yabancı dil olarak Türkçe öğretimi için kurulacak bir akreditasyon derneği, öğretime devam eden ya da kuruluş aşamasında olan dil merkezlerine belirlenen standartlarla rehberlik edecektir. Açılmış ve açlacak Türkçe dil öğretim okulların dil öğretim sürecinde akredite edilip daha üst düzeylerde dil öğretimine katkı sağlayacaktır. Türkçe öğretim merkezlerinde dil öğretiminin sadece eğitim bazlı olarak değil, aynı zamanda personel, okul yönetimi, fiziki yeterlilikler, öğrenci hizmetleri, öğrenci başarı takibi gibi geri plana atılmış diğer sorumlulukların da gelişimine destek verecektir.

\section{Yöntem}

Bu çalışmada yöntem olarak tasarım ve geliştirme çalışmalar için kullanılan araştırmalardan yararlanılmıştır. Tasarım geliştirme araştırmalarının iki tipi bulunmaktadır. Bunlar ürün-araç araştırmaları ve model araştırmalarıdır (Richey, Klein ve Nelson, 2004). Bu araştırmada ikinci tip tasarım ve geliştirme araştırması olan model araştırmalanı kullanılmıştır. Model araştırmaları model geliştirilmesi, geçerlenmesi ve kullanımını temel alan çalışmalardır ve bu süreçte daha önce bulunmayan tasarım model, süreç ya da standartları oluşturulabilir (Richey ve Klein, 2005). Bu yönüyle araştırmada Türkçe öğretim merkezleri için akreditasyon standartları oluşturulacağından model araştırmaları tercih edilmiştir.

Richey ve Klein'n (2005) model araştırmaları için vurguladıkları model ya da süreçte geliştirme, geçerleme ve kullanışl1lık incelemesi olmak üzere 3 basamak kullanılması önerilmektedir. Şengel'e (2013) göre bu basamakların tamamı kullanılacağı gibi sadece bir ya da birkaçının kullanıldığ1 çalışmalarda gerçekleştirilebilir. Bu çalışmada Türkçe öğretim merkezleri için akreditasyon standartları, bir modelin politika göstergeleri olarak geliştirilmiştir. Ancak geliştirilen bu standartların geçerleme ve kullanışlılık incelemeleri gerçekleştirilmeyecektir. Bu yönüyle çalışma model araşturmasının model geliştirme aşamasını içerecektir. Model geliştirme aşamasında alınyazın taraması ve detaylı görüşme yoluyla standartların oluşturulması sağlanmıştır.

Araştırmanın evrenini uluslararası düzeyde kullanımı bulunan ve erişime açık olan tüm akreditasyon kuruluşlarının akreditasyon amacıyla kullanılan belgelerindeki standartları oluşturmaktadır. $\mathrm{Bu}$ evrende yer alan belgelerden amaçlı örnekleme yöntemlerinden ölçüt örnekleme yöntemi kullanılmıştır. Örnekleme için ölçüt olarak uluslararası dil öğretimi yapan kurumlar için kullanılan standartlar ve ulusal düzeyde eğitim kurumları için standartlar temel alınmıştır. Bu ölçütlere uygun olarak yapılan örneklemede Commission on English Language Accreditation (CEA) standartları, Eğitim Fakülteleri Programları Değerlendirme ve Akreditasyon Derneği (EPDAD) standartları, Yükseköğretim Kalite Kurulu İngilizce hazırlık okulları için değerlendirme ölçütleri ve Avrupa Ortak Dil Portfolyosu örneklem olarak ele alınmıştır.

Araştırmada veri toplama aracı olarak Yükseköğretim Kalite Kurulu, Eğitim Fakülteleri Programları Değerlendirme ve Akreditasyon Derneği (EPDAD) standartları ve Avrupa Ortak Dil Portfolyosu'nun eğitim programlarını ve kalite standartlarını içeren dokümanlar kullanılmıştır. Veri toplama araçlarından standartlara yönelik veri elde edilmeye çalışılmıştır. Bu üç dokümandan elde edilen standartlar ve bunların göstergelerinden yola çıkılarak Türkçe öğretim merkezleri için standart önerileri geliştirilmeye çalışllmıştır. Öneriler geliştirilirken Türkçe öğretim merkezlerinde görev yapan 20 ögretim elemanı ile Yabancılara Türkçe Öğretiminde olabilecek kalite standartları hakkında görüş alınarak önerilecek olan standarda yönelik gerekçe ve olası durum ele alınmaya çalışılmıştır. 
İkiel, A. (2020). Yabancılara Türkçe öğretimi için akreditasyon standart önerileri. Journal of Human Sciences, 17(3), 780-791. doi:10.14687/jhs.v17i3.6022

Araştırmada verilerin analizi için öncelikle doküman incelemeden verilere betimsel analizler yapılmıştır. Betimsel analizde incelenen dokümanlarda yer alan standart ve bu standartlara ait göstergeler tek tek raporlanmıştır. Bu standartlardan yola çıkılarak Türkçe öğretim merkezleri için standart önerileri geliştirilmiştir. Bu standartlar geliştirilirken literatüre dayalı olarak gerekçelendirme yapılmaya çalışılmıştır. Geliştirilen standartlar ve gerekçeleri Türkçe öğretim merkezinde çalışan ögretim elemanları ile tartışılarak detaylandırılmaya çalışılmıştır.

\section{Bulgular \\ 3.1. Yabancılara Türkçe Öğretiminde Standartların Oluşturulmasına Yönelik Standart Ölçütleri}

Commission on English Language Accreditation (CEA) standartları, Eğitim Fakülteleri Programları Değerlendirme ve Akreditasyon Derneği (EPDAD) standartları, Yükseköğretim Kalite Kurulu İngilizce hazırlık okulları için değerlendirme ölçütleri ve Avrupa Ortak Dil Portfolyosu'nun öne çıkan özellikleri standartlar olarak incelenmiş ve bunlardan yararlanılmıştır. Yabancılara Türkçe Öğretimi alanında örnek alınabilecek akreditasyon derneklerinin standartları için Avrupa Dilleri İçin Ortak Dil Portfolyosu standartları incelenmiştir. Yabancılara Türkçe Öğretimi alanında hayata geçirilebilecek bir akreditasyon derneği için minimum yeterlilikler çerçevesinin ölçütleri doküman incelemelere dayalı verilerle bulgular elde dilip standartlar belirlenmiştir. Belirlenen standartlar yabancilara Türkçe öğreten dil merkezleri için genel bir kalite-akreditasyon çerçevesi oluşturabilir;

\subsubsection{Misyon}

Misyon bir örgütün varoluş sebebini anlatır, örgüt tarafından benimsenen bir misyon çalışanları motive eder, rakiplere karşı farklılıklarını dile getirir ve kuruma bir kimlik kazandırır (Dalay, Coşkun ve Altunışık, 2002). Misyon, açık ve anlaşılabilir bir metin olarak belirlenmeli, gerçekleştirilmek istenen şeyi anlatabilmeli ve kurumun sorumluluklanını ifade edebilmelidir. Kurumlar misyon oluşturma sürecinde çevresel koşulları gözden geçirmeli devamında kurumun yaptığ1 işi belirlemesi gerekmektedir. Çünkü misyonun bir bölümü kurumun yaptığ1 işi ifade etmektedir. Fakat misyon, kurumun sadece yaptığı iş değildir. Kurum, misyonunu oluştururken, durum analizi yapmalıdır (Muslu, 2014). Türkçe Öğretim Merkezleri, kurum personelinin ve kurumun öz farkındalıklarının olabilmesi, eğitimcilerin yabancı uyruklulara Türk dilini öğretirken onları güdüleyecek ve motivasyonlarını arttıracak şekilde açı bir dille ifade edilmiş kurum misyonuna sahip olmalıdır.

\subsubsection{Eğitim programı ve kur sinavları}

- Yabancı dil olarak Türkçe öğretimi programlarında ders için eğitim ve öğretim planı şekillendirilirken Avrupa Ortak Dil Portfolyosunda her kur için belirlenmiş olan yeterlilikler göz önünde bulundurulmalı ders planları ve eğitim programı bu yeterlilikleri dil öğrenenlere kazandıracak şekilde hazırlanmalıdır. Eğitim-öğretim yılı boyunca takip edilecek ders kitapları ve kaynaklar yine bu yeterlilikleri sağlayan yayınlar arasından seçilmelidir.

- Yabancilara Türkçe Öğretimi kurları sonunda yapılan ölçme ve değerlendirme sınavlarının kapsamı daha önce Avrupa Ortak Dil Portfolyosuna göre hazırlanmış olan ders içeriklerini kapsayacak bir düzenle oluşturulmalıdır. Bu sınavlar, kurların öğrenim çıktılarının dil öğrenenlere yansımasını ölçmelidir. Sorular bu çerçevede hazırlanmalıdır. Sınav puanlaması için daha önceden belirlenmiş olan puan ölçekleri kullanılmalıdır. Dil öğrenenlerin sınavda uygulanan dört beceri alanından da gerekli yeterliliğe sahip olduğunun belirlenebilmesi ve başarılı sayılabilmesi için her beceri alanı için en düşük başarı puanı belirlenmelidir. Kur sınavı sonunda gelebilecek öğrenci şikâyetleri için öğrencilere hatalarının açıkça anlatılabilmesi için sınav kâğıtlarında öğrencilerin hataları işaretlerle belirtilmeli ve konuşma sinavları öğrenci izniyle kayıt altına alınarak tekrar değerlendirme imkânı yaratılmalıdır.

\subsection{3. Öğretim elemanları}

- Türkçe öğretim merkezinin bünyesinde çalssan dil öğreticileri nitelik ve nicelik olarak Yabancılara Türkçe Öğretimi için gerekli yeterliliklere sahip olmalıdır. Dil öğreticilerinin lisans veya 
İkiel, A. (2020). Yabancılara Türkçe öğretimi için akreditasyon standart önerileri. Journal of Human Sciences, 17(3), 780-791. doi:10.14687/jhs.v17i3.6022

lisansüstü mezuniyetleri alanla ilgili olmalıdır veya Yabancılara Türkçe Öğretimi sertifikasına sahip olmalıdir.

- Türkçe öğretim merkezleri bünyelerinde çalıştıracakları eğiticilerin Yabancılara Türkçe Öğretimi içeren lisans-lisansüstü bölüm mezunu olmasına dikkat etmelidir.

- Türkçe öğretim merkezinde çalışacak eğitimcilerin üniversite içinde başka bölümlerden değil dil öğretim merkezinin kendi kadrosunda personel olması gerekmektedir.

- Kurum eğitim-öğretim personeli alımı, atanması, yükseltilmesi ve ders görevlendirmeleri süreçlerinde adil, açık ve şeffaf bir yol izlemelidir.

\subsubsection{Tesis ve tesis yeterlilikleri}

- Türkçe öğretim merkezleri, dil öğretimi yaparken dil öğrenenler ve dil öğreticileri için gerekli teknolojik altyapıya sahip olmalı ve personeline bu teknolojik altyapıyı etkin kullanabilmeleri için gerekli durumlarda destek ve eğitim sağlayabilme kapasitesine sahip olmalıdır.

- Türkçe öğretim merkezlerinde sınıf düzeni oluşturulurken sabit bir düzen yerine sınıftaki sıra, masa, projeksiyon, ışık vb. materyallerin ihtiyaç halinde veya etkinlikler yapılırken sınıf içinde değiştirebilmesine imkân sağlayacak şekilde oluşturulması gerekir. Sınıfın halihazırdaki fiziksel şartları göz önünde bulundurulmalı ve esnek bir yapı oluşturulmalıdır.

- Yabancilara Türkçe Öğretiminde sınıflarda maksimum verim sağlanabilmesi için hangi kurda en fazla ve en az kaç öğrenci olması ile ilgili detaylı bir çalışma olmamasına rağmen Barın (2004) dil öğretimi yapılan sınıfta ideal öğrenci sayısının 8-14 arasında olabileceğini ifade etmiştir. Harfitt (2012) öğrenci sayısının az olduğu yabancı dil öğretimi sınıflarında öğrencilerin derse katılım gösterme daha istekliği olduklarını ve öğretmenlerine daha fazla soru sorarak etkileşime girdiklerini belirtmiştir. Aynı çalışmada öğrenci mevcudiyeti az olan yabancı dil öğretimi sınıflarında öğrencilerin kendi içinde veya dil öğreten ile arasındaki kültürel engellerin daha rahat aşlıp heyecan seviyesinin daha kolay kontrol altına alınabildiğini ifade etmiştir. Aynı şekilde küçük dil sınıflarında dil öğrenenler sınıftaki arkadaşlarıyla bir bütünlük ve beraberlik gerçekleştirdikleri için daha rahat dil öğrenme ortamı bulabilir, derse daha fazla katılım göstererek öğretmenle daha fazla etkileşime girebilirler (Wang ve Finn, 2000). Bu bilgilerden yola çıkarak, Türkçe öğretim merkezlerinde sınıflardaki öğrenci sayısı dil öğreticilerinin her öğrenciyle ilgilenebilecekleri sayıda olmalıdır ve bu sayı her kurun kendi içindeki ihtiyaçlara göre değişim gösterebilir.

- Türkçe öğretim merkezi kendi bünyesinde dil öğrenenlerin ihtiyaçlarına yönelik okuma yapabilecekleri dil öğretimine uygun basit hikâye kitaplarından ve kelime öğretim setlerinden oluşan bir kütüphane bulundurmalıdır. Kütüphanenin barındıracağı kitaplar kur seviyelerine göre düzenlenmeli ve öğrenciler ihtiyaç duydukları zamanlarda bu kitaplara erişebilmelilerdir.

- Dil öğretim merkezi dil öğreticileri veya çalışanları için gerekli fiziksel alanlanı bulundurmalıdır. Dil öğreticilerinin ders dışı etkinliklerini (ödev hazırlama-okuma, soru hazırlama vb.) çalışmalarını yapabilecekleri bir çalışma alanı sunmalıdır. Kurum kayıt zamanları, sınav zamanları, dil öğrenenlerin veya aday öğrencilerin bilgi alma ihtiyaçlarını gözeterek öğrenci işleri personeli için rahat ve gerekli fiziksel alana sahip bir çalışma odası düzenlemelidir. Bu çalışma alanları için gerekli teknolojik altyapı sağlanmalıdır.

\subsection{5. İdari sorumluluklar}

- Türkçe öğretim merkezi idaresi kurum çalışanları için bir organizasyon şeması hazırlayarak bu görev dağ̣lımları veya iş tanımları (sınav komisyonu, kurum içinde çalışma kâğıtlanı hazırlanıyorsa sorumlu personel, konuşma kulüpleri vs.) her akademik yılbaşında personeline yazılı olarak tebliğ etmelidir.

- Türkçe öğretim merkezi bünyesinde çalışan eğiticilerin mesleki ve akademik gelişimleri için belli aralıklarla alanla ilgili akademik yayınların, çalışmaların veya dil öğretim setlerinin tartışlabileceği düzenli toplantılar düzenlemelidir.

- Dil öğretim merkezi çalışanlanını alanla ilgili yapılan kongre, seminer, çalıştay vb. gibi bilimsel aktivitelere katılımlarını teşvik etmelidir. Personelin kurum içinde yapacağı bilimsel çalışmauygulamalara yardımcı olmalıdır. 
İkiel, A. (2020). Yabancilara Türkçe öğretimi için akreditasyon standart önerileri. Journal of Human Sciences, 17(3), 780-791. doi:10.14687/ihs.v17i3.6022

- Türkçe öğretim merkezi performans değerlendirme kriterleri oluşturup personeline uygulamalıdır. Kurum performans değerlendirme sonucu kendisine uygun bir ödüllendirme sistemi oluşturarak personel verimliliğini arttırmaya yönelik bir uygulama hazırlayabilir.

\subsection{6. Öğrenci hizmetleri}

- Türkçe öğretim merkezinde dil eğitimine başlayacak öğrencilerin önemli bir kısmı ülke ve üniversite kültürüne aşina olmayacakları göz önünde bulundurulursa kurum öğrenciler için dil öğretiminde önce bir oryantasyon programı hazırlayıp uygulamalıdır. Bu oryantasyon döneminde öğrenciler ülkedeki veya üniversitedeki bazı temel sosyal veya resmi kurallar hakkında bilgi edindirilmelilerdir. Bu süreç ile öğrencilere; okul kuralları, şikâyet mekanizmaları, şehir içi ulaşım sistemleri vb. konularda bilgiler verilir. Öğrencilerin sene başında Türk dilini bilmeyecekleri düşünülürse bu eğitim süreci için üniversitelerde faaliyet gösteren yabancı öğrenci toplulukları ile iş birliği yapılabilir. Bu sayede öğrenci eğitime başlamadan öz güvenini yükselterek ve kendini daha rahat hissederek dil öğretimi için konsantrasyonunu yükseltecektir.

- Türkçe öğretim merkezleri akademik yılbaşında okula kayıt yaptıran fakat Türkçe bilgisi olan öğrenciler için bir seviye tespit sınavı düzenlemelidir. Bu sayede her öğrenci kendi dil gereksinimlerini karşılayacak dil öğretim kurundan eğitime başlayarak sınıf içi dil bilgisi dengeleri oluşturulacaktır.

- Türkçe öğretim merkezleri dil öğrenenler ve dil öğrenme adayları için okul hakkında bilgilerin (ücretler, kurallar vs.) bulunduğu ve iletişim yollarının açıklandığı bir web sayfasına sahip olmalıdır. Bu web sayfasında ayrıca öğrencilerin ihtiyaç duyabilecekleri diğer devlet kurumlarının (il göç idaresi, bağlı bulunulan üniversite, YTB vb.) web sayfaları için uzantilar bulunmalıdır.

- Türkçe öğretim merkezi dönem başında öğrenci kayıtlarını kabul ederken, öğrenci adayları ile anlayabilecekleri dillerde hazırlanmış bir öğrenci kayıt sözleşmesi hazırlamalı ve her öğrenci için okul kurallarını açıkça anlatan bir sözleşme yapmalıdır.

\subsection{7. Öğrenci başarıları}

- Türkçe Öğretim Merkezi kendi performansını gözlemleyebilmek, iş geliştirme çalışmalarını yapabilmek ve öz değerlendirme yapabilmek için öğrenci başarılarını yıllara ve kurlara göre Excel tabloları veya benzeri tablolarla arşivleyip bu tabloları dönem dönem gözden geçirip yorumlamalı öğrenci puanlarının değişimlerini değerlendirerek gereken önlemleri almalıdır.

- Kurum kur sonunda yapılan sınavlarda başarısız olan öğrencilerin eksiklerini tespit edip öğrenci hangi becerilerden veya konulardan zayıfsa bu konular üzerinde çalışma kâğıtları veya fazladan ödev vererek öğrenci başarısızlığının sürekli hale gelmesini önlemelidir.

\section{Sonuç ve Tartı̧̧ma}

Türkiye'de yabancı dil olarak Türkçe öğretimine kurumsal olarak yükseköğretim düzeyinde ilk defa 1984 yllında Ankara Üniversitesi Türkçe Öğretim Merkezinde (TÖMER) başlanmıştır (WEB4, 2019). Türk yükseköğretimde ilk akreditasyon faaliyeti 1994 y1lında Orta Doğu Teknik Üniversitesi'nin Mühendislik Fakültesinde bulunan iki programın ABET (Accreditation Board of Engineering and Technology- ABD) değerlendirme sürecinden geçmesiyle olmuştur (Süngü ve Bayrakç1, 2010). Yabanc1 dil olarak Türkçe öğretiminin ve yükseköğretimde akreditasyon hareketlerinin Türkiye'de uzun zamandır devam etmesine karşılık Yabancılara Türkçe Öğretimi alanında akreditasyon için herhangi bir çalışma yapılmamıştır. Yabancilara Türkçe Öğretimi için yapılan araştırmaların veya lisansüstü tezlerin tarandığı bazı çalışmalara göz atıldığında, 2014 yılında yapılan bir çalışmada 19812012 y1lları arasında Yabancılara Türkçe Öğretimi ana bilim dalında hazırlanan 147 lisansüstü tez konularına göre incelenmiş fakat bu alanda herhangi bir toplam kalite veya akreditasyon çalışmasına rastlanmamıştır (Büyükikiz, 2014). 2017'de yapılan bir başka çalışmada 2010-2016 yılları arasında Yabancılara Türkçe Öğretimi alanında uygulamaya dayanan 191 makale konularına göre incelenmiş bu akademik çalışmalar arasında herhangi 
İkiel, A. (2020). Yabancılara Türkçe öğretimi için akreditasyon standart önerileri. Journal of Human Sciences, 17(3), 780-791. doi:10.14687/jhs.v17i3.6022

bir akreditasyon veya toplam kalite çalışması bulunamamıştır (Biçer, 2017). Yaptığımız bu çalışma Türkçe Öğretim Merkezleri için kurabilecek bir akreditasyon derneği için; misyon, Eğitim programı ve kur sinavları, Öğretim elemanları, Tesis ve tesis yeterlilikleri, İdari sorumluluklar, Öğrenci hizmetleri, Öğrenci başarıları gibi ana standartlar belirlenmiştir. Bu çerçeve standardize ve akredite olacak Türkçe öğretim merkezlerin temel felsefesini ve taslağını oluşturmasına yardımcı olacaktır. Bu standartlar, standardizasyonun sebep olabileceği okullar arası tek tiplilik gibi olumsuz özelliklerin dil öğretim merkezlerinde oluşmaması göz önüne alarak oluşturulmuştur. Araştırmada akreditasyon standartlarını temellendirecek olan alt standartlar, standart göstergeleri, standartların kanıtları ve akreditasyon takvimi çalışılmamıştır.

Bu standartlar ile dil öğretim merkezleri arasında bir benzerlik oluşturularak seviye belirleme sınavlarında puan aralıklarının birbirlerine yaklaştırılması veya ortak puan aralıklarının oluşturulması gerekliliği ve ortak bir dil öğretim programına olan ihtiyaç vurgulanmıştır. Bu benzerliklerin oluşturulabilmesi ile bir dil öğretim merkezinden alınan Türkçe sertifikası ile bir başka kurumun verdiği Türkçe sertifikası birbirini yeterlilik noktasında karşılayabilecektir. Ortak eğitim programına ve puan aralıklarına sahip kurumların verdiği Türkçe sertifikalarının benzerleşmesi ile öğrencilerin dil okulu değiştirmesi durumunda akredite olan kurumlar birbirlerinin sertifikalarını tanıyarak okul değiştiren öğrencilerin eğitimini bıraktı̆̆ kur seviyesinden eğitimine devam edebilmesine imkân tanınabilir.

Belirlenecek ortak bir dil öğretim programı ile Türkçe öğretim merkezlerinde kur saatleri ve eğitimin süresi düzenlenerek gereğinden uzun akademik takvim uygulayan dil öğretim merkezleri için eğitim programları yeniden düzenlenerek oluşabilecek işgücü kaybının önüne geçilebilir. Gereğinden kısa süren eğitim programları sonucu dil öğrenenlerin zayıf bir dil öğretim programından geçerek akademik veya sosyal yaşantılarında karşılaşabilecekleri sorunlara önlem alınabilir.

Türkçe öğretim merkezlerinde akreditasyon için önerilen bu standartlar ile verilen dil eğitiminin yanı sıra öğrenci memnuniyetide göz önüne alınmıştır. Yabancı uyruklu öğrencilerin Türkiyede dil öğrendikleri süre boyunca dil merkezleri akredite olup daha aktivite kazanzactır. Dil öğretiminin seciyesi üst düzeye çılarılacak, öğrencilerin ülkeye adaptasyonu sağlanması kolaylaşacaktır. Yabanc1 öğrencilere okul-üniversite kuralları, dilekçe ve şikayet için izleyecekleri yollar, akademik takvim gibi konuların anlatılacağı oryantasyon eğitimi verilmesi alan için büyük bir katkı olacaktur. Göz ardı edilen bu sürecin dil öğretim merkezlerine kazandırılması ile Türkçe öğretiminin kalitesi yükseltilecek, eğitim döneminin başındaki yabancı uyruklu öğrencilerin, türk kültünü daha iyi benimsemelrien yardımcı olacaktır. Türkçe öğretimin önündeki problematik engeller ve soru işaretleri giderilerek konsantrasyon seviyelerinin arttırılması sağlanacaktır.

Sonuç olarak; Araştırmanın içerdiği bulgular ve sonuçlar Yabancılara Türkçe Öğretiminde yıllardan beri hala bir bütünlük oluşturulamadığın saptanmıştır. Hangi kurda kaç saat ders yapılacağı belirlenmemiştir. Hangi kurun hangi yeterlilikleri içermesi gerektiği konusu belirsizdir. Yabancilara Türkçe Öğretim standartlarının ve felsefesinin öğretimi konularında fikir birliği sağlanıp hayata geçirilememiştir.

\section{Öneriler}

- Bu çalışmada ortaya konan standartlar yaygınlaştırılmalıdır. Yabancılara Türkçe Öğretiminde akreditasyon veya toplam kalite standartlarının oluşturulmasında bu çalışmanın temel bulgularından yararlanılmalıdır.

-Yabancilara Türkçe Öğretiminin hedef, içerik öğrenme-öğretme süreç-yöntemleri ile ölçme ve değerlendirmelerine yönelik eğitim-öğretim alanında bir bütünlük ve düzen sağlanmalıdır. Yabancı dil olarak Türkçe öğretimi için Avrupa Dilleri Ortak Dil Portfolyosu örnek alınmalıdır. Bir eğitim programı geliştirilmeli veya portfolyonun Yabancılara Türkçe Öğretimi için uygunluğu araştırılarak benzer bir eğitim programı oluşturulmalıdır. 
İkiel, A. (2020). Yabancılara Türkçe öğretimi için akreditasyon standart önerileri. Journal of Human Sciences, 17(3), 780-791. doi:10.14687/jhs.v17i3.6022

- Yabancı dil olarak Türkçe öğretiminde kurların minimum veya maksimum kaç hafta süreceği dil becerilerinin öğrencilere ne kadar süreyle kazandırılabileceği araştırılmalıdır.

- Türkçe öğretim merkezi idarecileri, alanla ilgili çalışması olan akademisyenler ve bu alanda tecrübe sahibi eğiticilerin katılım göstereceği bir çalıştay düzenlenerek kurulabilecek bir akreditasyon derneği için standartlar netleştirilebilir.

\section{Kaynakça}

Aktan, C., \& Gencel, U. (2007). Değişim Çağında Yüksek Öğretim. Yaşar Üniversitesi Yayını. Barın, E. (2004). Yabancılara Türkçe Öğretiminde İlkeler. Türkiyat Araştırmalar Dergisi , 1, 19-30.

Biçer, N. (2017). Yabancılara Türkçe Öğretimi Alanında Yayınlanan Makaleler Üzerine Bir Analiz Çalışması. Pamukkeale Sosyal Bilimler Enstitïsü Dergisi, 27, 240-241.

Boylu, E. (2019). Yabanculara Türkşe Ögrretiminde Ölcme Değerlendirme Uygulamalar Ve Standart Olusturma (Doktora Tezi). YÖK Tez Merkezi veri tabanından erissildi (Tez No: 542435).

Boylu, E. ve Başar, U. (2016). Türkçe Öğretim Merkezlerinin Güncel Durumu ve Standartlaştırılması Üzerine. Akademik Sosyal Araștormalar Dergisi, 24, 309-324.

Büyükikiz, K. (2014). Yabancılara Türkçe Öğretimi Alanında Hazırlanan Lisansüstü Tezler Üzerine Bir İnceleme. Mustafa Kemal Üniversitesi Sosyal Bilimler Enstitüsü Dergisi, 11(25), 203-213

CEF. (2001). Common European Framework Of Reference For Language. Cambridge: Cambridge Universty Press.

Dalay, İ., Coşkun, R. ve Altunışık, R. (2002). Çağdaş Yönetim Yaklaşımları. İstanbul: Beta Yayınları.

Gencel, U. (2001). Yükseköğretim Hizmetlerinde Toplam Kalite Yönetimi Ve Akreditasyon. Dokuz Eylül Üniversitesi Sosyal Bilimler Enstitïï̈ Dergisi, 3(3), 193.

Gökalp, Z. (1975). Türkçülï̈̈̈̈n Esaslar. İstanbul: Sebil Matbaac1lk.

Güler, G. (2005). Avrupa Konseyi Ortak Dil Kriterleri Çerçeve Programı Ve Türkiye'de Yabanc1 Dil Öğretim Süreçleri. Trakya Üniversitesi Sosyal Bilimleri Dergisi, 6(1), 91-92.

Harfitt, G. (2012). Class Size And Language Learning İn Hong Kong: The Studentse Perspective. Educational Research 54, 331-342.

Hesapçıŏlu, M., Bakioğlu, A. ve Baltac1, R. (2001). Öğretmen Eğitiminde Sorumluluk ve Akreditasyon. Kuram ve Uygulamada Eğitim Bilimleri Dergisi 1(1), 143-160.

Muslu, Ş. (2014). Örgütlerde Misyon Ve Vizyon Kavramlarının Önemi. HAK-İS Uluslararası Emek ve Toplum Dergisi, 3(5), 150-171.

Okur, A. ve Keskin, F. (2013). Yabancılara Türkçe Öğretiminde Kültürel Ögelerin Aktarımı: İstanbul Yabancilar İçin Türkçe Öğretim Seti Örneği. International Journal of Social Science 6(2), 16-38.

Richey, R. C. ve Klein, J. D. (2005). Developmental Research Methods: Creating Knowledge From Instructional Design And Development Practice. Journal of Computing in Higher Education, 16(2), 23-38

Richey, R., Klein, J. ve Nelson, W. (2004). Handbook Of Research For Educational Communications And Technology. D. H. Jonassen (Ed.) Development Research: Studies Of Instructional Desing And Development, ss. 1099-1130. New Jersey: Lawrence erlbaum Associates Inc.

Süngü, H. ve Bayrakçı, M. (2010). Bolonya Süreci Sonrası Yükseköğretimde Akreditasyon Çalısmaları. Türk Eğitim Bilimleri Dergisi 8(4), 900-901.

Şengel, E. (2013). Öğretim Teknolojilerinin Temelleri: Teoriler, Araștırmalar, Eğilimler. E. Şengel, K. Çağıltay ve Y. Göktaş (Ed.), Tasarım Ve Geliştirme Araştırmaları, ss. 327-340. Ankara: PagemA Akademi.

Ülker, N. (2015). Yabanc Dil Hažrlk Programlarmın Akreditasyonunun Akademik Kaliteye Etkisi Üzerine Uluslararası Bir Araștırma (Yüksek Lisans Tezi). YÖK Tez Merkezi veri tabanından erişildi (Tez No: 414419). 
İkiel, A. (2020). Yabancılara Türkçe öğretimi için akreditasyon standart önerileri. Journal of Human Sciences, 17(3), 780-791. doi:10.14687/jhs.v17i3.6022

Wang, M. ve Finn, J. (2000). How Small Classes Help Teachers Do Their Best. Philadelphia: Temple University Center for Research in Human Development.

WEB1, http://www.goc.gov.tr/icerik3/gecici-koruma_363_378_4713 adresinden 17.04.2019 tarihinde erişilmiştir.

WEB2, https://istatistik.yok.gov.tr/ adresinden 20.02.2019 tarihinde erişilmiştir

WEB3, http://www.ytb.gov.tr/kurumsal/faaliyet-raporlari adresinden 25.11.2018 tarihinde erişilmiştir.

WEB4, http://tomer.ankara.edu.tr/hakkimizda/ adresinden 30.06.2019 tarihinde erişilmiştir.

\section{Extendend English Summary}

Starting to learn a foreign language also means understanding and understanding this culture. Language education in which culture is not taught is not language education, but it means memorizing the rules of that language (Okur \& Keskin, 2013). Quality standards should be determined by considering language standards in every respect, not just grammar teaching. Accreditation will help this process. Accreditation is one of the factors in total quality servants and it is a method created to guarantee the quality of programs and services offered to the public in many countries and areas of the world with a systematic approach (Gençel, 2001).

\section{Aim of the study}

Although language teaching centers that serve teaching Turkish to foreigners have generally adopted the same mission, they differ from each other in language teaching processes. The aim of this study is to have common quality standards while preserving the unique structure of language teaching centers and to offer quality standards proposal to the accreditation union in Turkish teaching that can be established in the future.

\section{Method}

In this study, researches used for design and development studies were benefited as a method. There are two types of design and development researches. They are product-tool researches and model researches (Richey, Klein \& Nelson, 2004). In this research, model researches, the second type of design and development research, were used. Model researches are studies based on model development, validation and usage, and during this process, design model, process or standards not existed before can be created (Richey \& Klein, 2005). From this aspect, model researches were preferred because accreditation standards will be established for Turkish teaching centres.

\section{Results}

In the field of teaching Turkish to foreigners, when the standards of the accreditation associations that can be taken as an example and the Common Language Portfolio for European Languages are examined, the qualifications given below will form the minimum qualifications framework for an accreditation association that can be implemented in the field of Teaching Turkish to Foreigners. Seven accreditation standards have been set for teaching Turkish to foreigners. These standards are mission, curriculum and exam, personnel, school and equipment, administrative responsibilities, student services, student achievements. There has been no accreditation process in Turkish teaching centers before. For this reason, standards have been kept as simple as possible while recommending. The accreditation of Turkish teaching centers will both help improve these standards and increase the quality in language centers.

The study draws the main standards framework for an accreditation association that can be established for Turkish Teaching Centers. These standards were created by taking into consideration that negative features such as uniformity brought along with standardization do not occur in language teaching centers. In the research, sub-standards, standard indicators, evidence of standards and accreditation calendar that will base the accreditation standards have not been studied. 
By establishing a similarity between these standards and language teaching centers, the need for a common language teaching program and the need for a common language teaching program are emphasized in the placement tests.With the establishment of these similarities, the Turkish certificate obtained from a language training center and the Turkish certificate issued by another institution can meet each other at the point of competence.With the similarity of Turkish certificates issued by institutions with joint education programs and score ranges, if students change their language schools, accredited institutions may be given the opportunity to continue at the exchange level of students who change their education.Language schools recognize the validity of each other's certificates.

With a common language teaching program to be determined, labor loss can be prevented by reorganizing the training programs for language teaching centers that implement longer academic calendars by adjusting the training hours and duration in Turkish education centers. As a result of less than necessary training programs, language learners may be subjected to a weak language teaching program. Short programs can be reorganized and measures can be taken for the problems students may face in their academic or social life. The most efficient time should be used for teaching Turkish.

In addition to language training provided with these standards recommended for accreditation in Turkish languamge teaching centers, customer satisfaction is also taken into account. An orientation program should be organized for students who will study Turkish language, apart from language schools language teaching. It will be a great contribution to provide students with orientation training that will explain the topics such as school-university rules, the paths they will follow for petitions and complaints, and the academic calendar. By adding this neglected process to the language teaching centers, the question marks on the heads of foreign students at the beginning of the education period will be removed and the concentration levels will be increased. 